\title{
Banks, relative performance, and sequential contagion
}

\author{
Sudipto Bhattacharya - Charles A. E. Goodhart • \\ Pojanart Sunirand · Dimitrios P. Tsomocos
}

Published online: 24 July 2007

(C) Springer-Verlag 2007

\section{Erratum to: Econ Theory (2007) 32:381-398 DOI 10.1007/s00199-006-0190-7}

The original version of this article unfortunately contained a mistake. The sequence of the author names was incorrect. The corrected sequence is given below.

Sudipto Bhattacharya, Charles A. E. Goodhart, Pojanart Sunirand, Dimitrios P. Tsomocos

The online version of the original article can be found under doi:10.1007/s00199-006-0190-7.

S. Bhattacharya

London School of Economics and CEPR, London, UK

C. A. E. Goodhart · P. Sunirand · D. P. Tsomocos

Financial Markets Group,

London School of Economics,

London, UK

D. P. Tsomocos $(\varangle)$

Saïd Business School and St. Edmund Hall, University of Oxford,

Park End Street, Oxford OX1 1HP, UK

e-mail: dimitrios.tsomocos@sbs.ox.ac.uk 